\title{
THE INFLUENCE OF MARKETING MIX AND WORD OF MOUTH TOWARDS BRAND IMAGE AND USAGE OF ONLINE BIKE USAGE
}

\author{
Fandi Yanuar Rahman ${ }^{* 1}$, Lilik Noor Yuliati**), and Megawati Simanjuntak ${ }^{* *)}$ \\ *) School of Business, IPB University \\ Jl.Raya Pajajaran,Bogor 16151 \\ ${ }^{* *}$ Department of Family and Consumer Sciences, Faculty of Human Ecology, IPB University \\ Gedung GMSK Lantai 2, IPB Dramaga Campus Bogor 16680
}

\begin{abstract}
This research aimed to analyze the influence of marketing mix and word of mouth towards brand image and the usage of online bike. The research design used descriptive, with the survey conducted using questionnaire as the tool of interview. The sampling technique used systematic random sampling with a kish grid approach. Kish grid is a method for selecting members within a household to be interviewed, this method was commonly used in marketing research especially on household survey. The exact 200 samples were obtained for the research. There were four latent variabels in this research, included marketing mix and word of mouth as independent variables, brand image as intervening variables and the usage of online bike as dependent variables. The datawere processed using descriptive through SPSS 24 and Structural Equation Modelling (SEM) method by LISREL 8.7 software. The results of this research revealed thatmarketing mix influenced positively and significantly toward the brand image; word of mouth influenced positively and significantly toward the brand image; marketing mix influenced positively and significantly toward the usage of online bike; word of mouth influenced positively and significantly toward the usage of online bike; and brand image influenced insignificantly toward the usage of online bike.
\end{abstract}

Keywords: marketing mix, brand image, word of mouth, online bike, service usage

\begin{abstract}
Abstrak: Penelitian ini bertujuan menganalisis pengaruh dari marketing mix dan word of mouth terhadap brand image dan perilaku penggunaan ojek online. Penelitian ini bersifat deskriptif dengan survei yang dilakukan menggunakan kuesioner sebagai alat wawancara. Teknik pengambilan sampel menggunakan systematic random sampling dengan pendekatan kish grid. Kish grid adalah sebuah metode yang digunakan untuk memilih anggota keluarga untuk diwawancarai, metode ini biasa digunakan dalam penelitian marketing khususnya dalam pendekatan rumah tangga. Penelitian ini menggunakan 200 sampel yang dikumpulkan. Terdapat empat variabel laten dalam penelitian ini, yaitu marketing mix dan word of mouth sebagai variabel independen, brand image sebagai variabel intervening dan penggunaan ojek online sebagai variabel dependen. Data deskriptifyang diperoleh diolah menggunakan SPSS 24 dan data Structural Equation Modeling (SEM) diolah menggunakan LISREL 8.7. Hasil penelitian ini menunjukkan bahwa marketing mix berpengaruh positif dan signifikan terhadap brand image; word of mouth berpengaruh positif dan signifikan terhadap brand image; marketing mix berpengaruh positif dan signifikan terhadap penggunaan ojek online; word of mouth berpengaruh positif dan signifikan terhadap penggunaan ojek online; dan brand image dipengaruhi tidak signifikan terhadap penggunaan ojek online.
\end{abstract}

Kata kunci: marketing mix, brand image, word of mouth, perilaku penggunaan, ojek online

\footnotetext{
${ }^{1}$ Corresponding author:

Email: fandyanuarahman@gmail.com
} 


\section{INTRODUCTION}

Public transportation is an absolute requirement of every individual these days, the high amount of activity and mobility in each individual requires them to use vehicles as a means of transportation. Public transportation then becomes a primary requirement for every individual today. This is supported by an increase in the population of Indonesia as well as an increase in the volume of vehicles. This phenomenon raises opportunities to conduct business in the field of effective and efficient transportation service providers and easily accessible and accessible to consumers online. According to Wardhana and Konadi (2015), online motorcycle taxi users in Indonesia amounted to $18,421,339$ in 2015.

There are three brands of online motorcycle taxi companies with the largest rated by consumer, this is based on the results of a survey conducted by the Indonesian Consumers Foundation (YLKI), the three online motorcycle taxi brands with the highest rating of consumers are Go-jek, Grab, and Uber (YLKI, 2017). YLKI conducted a survey of 4,688 respondents who were consumers of online motorcycle taxis with the highest rating being Go-jek (72.6\%), Grab (66.9\%) and Uber (51\%).

Companies providing online-based transportation services are starting to emerge and result in intense competition, which has an impact on consumers who want to use online transportation services, especially online motorcycle taxis. These companies are intensively engaged in marketing their products so that consumers choose the services they offer as the main choice for using public transportation.

These are the efforts of the company to formulate a marketing strategy through a marketing mix, Rahman (2011) states that each type of product has its own marketing mix strategy. Generally consumers not only see a product only from one side, but in a multidimensional value of the quality of the product itself. Kotler (2004), states that marketing mix is tools that can be applied in the process of product offering by a company to influence the sales process. The marketing mix is controlled variables that are combined to produce the expected response from the target market. Business services are very complex, because many elements influence them, such as the organization's internal system, physical environment, personal contacts, advertising, billing and payments, comments from the mouth to mouth, and so on. Therefore Gronroos in Kotler (2000) states that in the concept of service marketing involves several elements in the implementation of marketing activities, not only from the external marketing side but also from internal marketing and interactive marketing.

Factors that influencing consumer usage behavior are not only marketing efforts of the company, but there are some parts that can influence the behavior of consumer use as well as the strength of WOM (Word of Mouth). According to Sernovitz (2006), WOM is a conversation that naturally happens between people. According to Lupiyoadi (2006), word of mouth is a form of promotion in the form of word of mouth recommendations about the goodness of a product.

With thus it can be concluded that word of mouth is communication carried out by consumers who have made a purchase and told their experience about the product or service to others so that indirectly the consumer has carried out a promotion that can attract other consumers who listen to the conversation.

The creation of a brand image is also a major factor affecting the behavior of online motorcycle taxi consumers. Keller defines brand image as a perception of the brand as reflected by the brand itself in memory when a consumer sees the brand. The conceptual model of brand image according to Keller (1998) includes brand attributes, brand profits and brand attitudes. Based on several previous studies, brand image has different final results on the dependent variable. Such as study from Aprilia (2016), the results show that brand image influences consumer purchasing decisions. Meanwhile, a study from Merthayoga and Sunaryo (2013) shows insignificant results between brand image variables towards consumer purchase interest.

The purpose of this research is to analyze the effect of marketing mix and WOM on online motorcycle taxi brand image, analyze the influence of marketing mix and WOM on the behavior of online motorcycle taxis analyze the influence of brand image on the behavior of online motorcycle taxi usage, and formulate managerial implications that can be applied to companies in managing online motorcycle taxi marketing activities. 


\section{METHODS}

This study took place in the area of Ciluar Asri Housing, North Bogor District, Bogor City. This research was conducted for three months from July to October 2017. The approach used in this study was a descriptive quantitative approach with a survey method involving respondents at the household level.

The data used in this research are primary data using questionnaire instruments that have been filled out by respondents. The primary data referred to in this study, such as respondent data regarding the use of online motorcycle taxi in the form of demographic characteristics, vehicle ownership, usage behavior, marketing mix, word of mouth, and brand image.

The sampling technique used in this study was systematical random sampling. Determination of respondents was done by the kish grid approach. This method is widely used in marketing research, especially household surveys. This study uses a sample of 200 people who are considered to have been able to represent the population, which has 750 heads of households in the Ciluar Asri Housing area. This study involved respondents at the household level.

The technique of data collection is done through respondents who have been determined using a questionnaire instrument. After determining the criteria of suitable respondents, interviews were conducted with respondents who were guided using a questionnaire instrument which included the variables of marketing mix, word of mouth, brand image, and usage behavior. Data processing in this study was carried out with several analyzes. The analysis used included descriptive analysis using SPSS 24, and Structural Equation Modeling (SEM) using LISREL 8.7.

The framework based on a review of the theory which is the main source in a study and based on several previous studies. In some previous studies, marketing mix, word of mouth, and brand image were inseparable components in influencing consumer behavior to consume an item or service. Like in the research conducted by Nur (2014), study showed there were four variables, such as marketing mix and word of mouth as the dependent variable, brand image as an intervening variable, and consumer decisions as independent variables. In this study, marketing mix and word of mouth are used to see how much influence these variables have in influencing consumer decisions through brand image variables in consuming goods. The results of the study are, there is a significant influence between the marketing mix variables on brand image, and also indicated by the influence of WOM on purchasing decisions, but there is no significant influence between WOM on brand image and the effect of brand image on purchasing decisions. As for illustration, the frame of mind and the hypothesis will be presented in Figure 1:

H1 : Marketing mix has a significant effect on Brand Image

H2 : Word of Mouth has a significant effect on Brand Image

H3 : Marketing mix has a significant effect on Usage Behaviour

H4 : Word of Mouth has a significant effect on Usage Behaviour

H5 : Brand image has a significant effect on Usage Behaviour

Based on the previous research, the same variable is used in this study, there are marketing mix (product, place, promotion, price, physical evidence, people, and process), word of mouth, brand image, and usage behavior towards online motorcycle taxi services. To get good research results, it was identified the influence of marketing mix and WOM on online motorcycle taxi brand image, identification of the influence of marketing mix and WOM on the behavior of online motorcycle taxi, and identification of the influence of brand image on the behavior of online motorcycle taxi.

\section{RESULTS}

\section{Demographic characteristics}

The demographic data has been obtained through 200 respondents and data processing is carried out to produce relevant information about respondents. Demographic characteristics consist of gender, age group, education level, occupation, and expenditure/ allowance per month. Table 1 will explain the demographic characteristics of the respondents in this study. 


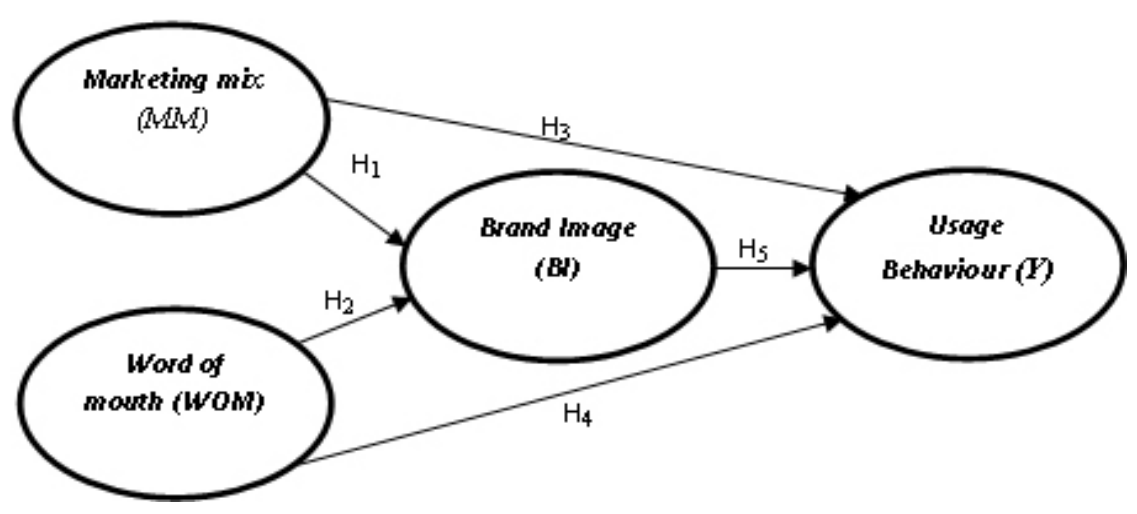

Figure 1. Research framework

Table 1. Demographic characteristics

\begin{tabular}{|c|c|c|c|}
\hline Respondent characteristics & Category & Number of respondents (n) & Percentage $(\%)$ \\
\hline \multirow[t]{2}{*}{ Sex } & Male & 62 & 31.0 \\
\hline & Female & 138 & 69.0 \\
\hline \multirow[t]{5}{*}{ Age Group } & $5-24$ years old & 93 & 46.5 \\
\hline & $25-35$ years old & 71 & 35.5 \\
\hline & $36-45$ years old & 20 & 10.0 \\
\hline & $46-55$ years old & 11 & 5.5 \\
\hline & $>55$ years old & 5 & 2.5 \\
\hline \multirow[t]{5}{*}{ level of education } & Junior High School & 12 & 6.0 \\
\hline & Senior High School & 47 & 23.5 \\
\hline & Diploma & 9 & 4.5 \\
\hline & Bachelor & 117 & 58.5 \\
\hline & Postgraduate & 15 & 7.5 \\
\hline \multirow[t]{8}{*}{ Occupation } & Student & 21 & 10.5 \\
\hline & College Student & 78 & 39.0 \\
\hline & Housewife & 9 & 4.5 \\
\hline & Professional & 6 & 3.0 \\
\hline & Entrepreneurship & 12 & 6.0 \\
\hline & Private employees & 48 & 24.0 \\
\hline & Government employees & 16 & 8.0 \\
\hline & Others & 10 & 5.0 \\
\hline \multirow[t]{6}{*}{ Monthly expenses } & $\leq \mathrm{Rp} 700,000$ & 25 & 12.5 \\
\hline & Rp700,001 - Rp1,000,000 & 27 & 13.5 \\
\hline & $\mathrm{Rp} 1,000,001-\mathrm{Rp} 1,500,000$ & 25 & 12.5 \\
\hline & $\mathrm{Rp} 1,500,001-\mathrm{Rp} 2,000,000$ & 26 & 13.0 \\
\hline & $\mathrm{Rp} 2,000,001-\mathrm{Rp} 3,000,000$ & 41 & 20.5 \\
\hline & $-\geq \mathrm{Rp} 3,000,001$ & 56 & 28.0 \\
\hline
\end{tabular}

Based on theTable 1, respondents from this study were dominated by women with a total percentage reaching almost 70 percent. Nearly half the population of this study belongs to the 15-24 year age group, the least respondents in this study were $>55$ years old, which is around 2.5 percent. Based on the level of education, respondents from this study were dominated by the level of undergraduate education. About 6 out of
10 respondents from this study had undergraduate education. Based on the results of the study, the work was dominated by students, as many as 4 out of 10 sample studies were students. Expenditures per month are dominated by the amount of expenditure per month $\geq \mathrm{Rp} 3,000,001$ with a percentage of almost 30 percent. 


\section{Behavior of the Use of Online Motorcycle taxis}

Based on the results of the study, there were three online motorcycle taxi brands mostly used by respondents, which are Go-jek, Grab and Uber. There were four aspects used to assessing behavior of the use of online motorcycle taxis including been using online motorcycle taxis, frequency of use, payment method, and feedback. The classification of the behavior of online motorcycle taxi can be seen in Table 2 .

Based on Table 2, the respondents rating of online motorcycle taxi users are Grab brand users (96.0\%), Go-jek (89.5\%), and Uber (56.5\%). The frequency of use with the rarely used category is dominated by Uber (66.4\%), the frequently used category is dominated by Grab (46.9\%) and always used is dominated by Grab $(12.5 \%)$. The majority of Uber user respondents always pay in cash, while 3 out of 10 respondents Go-jek pay non-cash using Go-pay. Most Grab user respondents gave ratings as feedback, more than 10 percent of Uber users gave comments as feedback and 16.2 percent of examples of Go-jek users gave ratings and comments as feedback.

The reason for choosing an online motorcycle taxi brand is divided into 7 categories, there are price, easy to get, convenience, security, frequent promotions, payment methods and drivers. Based on the results of the study, the price became the main rating while the method of payment was the least rating. This results are in line with Monroe and Allard CR van Riel (2005) research results, stating that price is an economic sacrifice made by customers to obtain products or services. However, for the order of reasons for choosing an online motorcycle taxi there is a slight difference between one another.

\section{Ranking of Reasons for Choosing Online Motorcycle taxis}

Based on the results of the study, there are seven aspects as the reasons for respondents to choose an online motorcycle taxi brand. The first aspect is the price with ranking sequence Uber, both Go-jek, and the third is Grab. The second aspect is often promotion with ranking sequence Grab, second is Uber, and the third is Go-jek. The third aspect is comfort with ranking sequence Uber, second Go-jek, and the third is Grab. The fourth aspect is security with ranking sequence Uber, second Grab, and the last is Go-jek. The fifth aspect is easily obtained with the ranking sequence Grab and the second is Go-jek, in the easy aspect to obtain the Uber brand has no rating due to the absence of answers from respondents. Then the sixth aspect is the driver with ranking sequence Uber, second Grab, and the third is Go-jek. The seventh aspect is the method of payment with ranking sequence Uber, second Grab, and the third is Go-jek.

Table 2. Behavior of the use of online motorcycle taxis

\begin{tabular}{lccc} 
& \multicolumn{1}{c}{ Aspect } & \multicolumn{3}{c}{ Percentage (\%) } \\
\cline { 2 - 4 } & Go-jek & Grab & Uber \\
\hline Been Using Online Motorcycle Taxi & & & \\
Yes & 89.5 & 96.0 & 56.5 \\
No & 10.5 & 4.0 & 43.5 \\
Frequency of use & & & \\
rare & 48.6 & 40.6 & 66.4 \\
often & 39.7 & 46.9 & 24.8 \\
always & 11.7 & 12.5 & 8.8 \\
Payment Method & & & \\
cash & 59.2 & 88.0 & 96.5 \\
Non-cash & 33.5 & 8.3 & 3.5 \\
Cash and non-cash & 7.3 & 3.6 & 0 \\
Feedback & & & \\
Rating & 81.0 & 84.9 & 83.2 \\
Rating and comment & 19.0 & 15.1 & 16.8 \\
\hline
\end{tabular}


Description of Variable Indicators Marketing Mix, Word of mouth, Brand Image, and Use Behavior

Four variables in this research was classified into three. There are use behavior as the endogenous variable (Y), marketing mix and word of mouth as exogenous variable (X1 and X2), and brand image as intervening variable (Z). Furthermore, for an explanation of the indicator variables can be seen in Table 3 .

The majority of respondents online motorcycle taxis users agree with the indicators contained in the marketing mix variable, these indicators are product, price, physical, process, promotion, human resources, and place. Online motorcycle taxi consumers agree that the factors applied in the process of offering services and facilities provided by online motorcycle taxis include the seven dimensions of the indicator when compared to other public transportation. Most respondents of online motorcycle taxi users agree on word of mouth indicators such as giving recommendations to the closest person, but disagree with the indicators talking about negative online motorcycle taxis.

The majority of respondents agree with the brand image indicator, where the community agrees about their perception in seeing the reflection of a brand itself into their thinking when they see an online motorcycle taxi. In usage behavior, half of the total respondents choose to travel during peak hours using online motorcycle taxis, give ratings after driving and using motorcycle taxis online on their own initiative.

Table 3. Indicator variables

\begin{tabular}{|c|c|c|}
\hline Latent variable & Indicator variable & Code \\
\hline \multicolumn{3}{|c|}{ Marketing Mix (X1) } \\
\hline \multirow[t]{3}{*}{ Product } & 1. Using online motorcycle taxi is more convenient than other public transportation & MMP1 \\
\hline & $\begin{array}{l}\text { 2. Services provided by online motorcycle taxi services are better than other public } \\
\text { transportation }\end{array}$ & MMP2 \\
\hline & 3. Online motorcycle taxis are the right choice for public transportation to save time & MMP3 \\
\hline \multirow[t]{3}{*}{ Price } & 1. The prices provided by online motorcycle taxis are comparable to the services & MMH1 \\
\hline & 2. Online motorcycle taxis often offer discounts & MMH2 \\
\hline & 3. The prices offered by online motorcycle taxis are reliable so there is no need to bargain & MMH3 \\
\hline \multirow[t]{3}{*}{ Physical Evidence } & 1. The appearance of online motorcycle taxi drivers is always neat & MMPF1 \\
\hline & 2. The motorcycle used by online motorcycle taxis have a good conditions & MMPF2 \\
\hline & 3. Online motorcycle taxi drivers always use attributes that have a company logo & MMPF3 \\
\hline \multirow[t]{3}{*}{ Process } & 1. Running an online motorcycle taxi application is very easy before make an order & MMPS1 \\
\hline & 2. Online motorcycle taxis have an easy payment system & MMPS2 \\
\hline & $\begin{array}{l}\text { 3. Information about usage of online motorcycle taxis is always available to make it easier } \\
\text { for consumers }\end{array}$ & MMPS3 \\
\hline \multirow[t]{4}{*}{ Promotion } & 1. The advertising content displayed by online motorcycle taxis is interesting & MMPR1 \\
\hline & 2. Promotions about online motorcycle taxis can be obtained anywhere & MMPR2 \\
\hline & $\begin{array}{l}\text { 3. The contents of the message in the promotion of online motorcycle taxis are easy to } \\
\text { understand }\end{array}$ & MMPR3 \\
\hline & 4. Promotions provided by online motorcycle taxis are in accordance with reality & MMPR4 \\
\hline \multirow{3}{*}{$\begin{array}{l}\text { Participant } \\
\text { (people) }\end{array}$} & 1. Online motorcycle taxis has a friendly drivers & MMSD1 \\
\hline & 2. Online motorcycle taxi drivers have a good driving skills & MMSD2 \\
\hline & 3. Online motorcycle taxi drivers always offer passengers to use helmets & MMSD3 \\
\hline \multirow[t]{4}{*}{ Place } & 1. Online motorcycle taxis have a lot of driver availability & MMT1 \\
\hline & $\begin{array}{l}\text { 2. Online motorcycle taxi drivers are ready to receive orders whenever needed through the } \\
\text { application }\end{array}$ & MMT2 \\
\hline & 3. Online motorcycle taxis have a huge scope of delivery area & MMT3 \\
\hline & 4. Online motorcycle taxi applications are easy to obtained & MMT4 \\
\hline
\end{tabular}


Table 3. Indicator variables (continue)

\begin{tabular}{|c|c|c|}
\hline Latent variable & Indicator variable & Code \\
\hline \multirow{5}{*}{$\begin{array}{l}\text { Word of Mouth } \\
\text { (X2) }\end{array}$} & 1. I feel need to discuss negative things about motorcycle taxis online after using them & WOM1 \\
\hline & 2. I feel need to give recommendations to use online motorcycle taxis to others & WOM2 \\
\hline & 3. I use social media to talk about online motorcycle taxis & WOM3 \\
\hline & 4. I get the information about online motorcycle taxi services from other people & WOM4 \\
\hline & 5. I often to discuss the advantages of online motorcycle taxis with the closest person & WOM5 \\
\hline \multicolumn{3}{|l|}{ Intervening } \\
\hline \multirow[t]{5}{*}{ Brand Image $(Z)$} & $\begin{array}{l}\text { 1. When I heard the word "online motorcycle taxis" I easily remembered one brand of } \\
\text { online motorcycle taxis company }\end{array}$ & BI1 \\
\hline & 2. Online motorcycle taxi consumers are people who have a high level of mobility & $\mathrm{BI} 2$ \\
\hline & 3. I feel safe from crime if I use an online motorcycle taxi & $\mathrm{BI} 3$ \\
\hline & $\begin{array}{l}\text { 4. Online motorcycle taxi drivers have been selected by the company so their reputation } \\
\text { and credibility are good }\end{array}$ & $\mathrm{BI} 4$ \\
\hline & 5. I use certain online motorcycle taxi brands for reasons of domestic brands & $\mathrm{BI} 5$ \\
\hline \multicolumn{3}{|l|}{ Endogenous } \\
\hline \multirow[t]{5}{*}{ Use Behavior (Y) } & 1. I travel during rush hour using online motorcycle taxi & Y1 \\
\hline & 2. I use online motorcycle taxis as the main choice of public transportation & Y2 \\
\hline & 3. I prefer to use cash payment method for online motorcycle taxi payment & Y3* \\
\hline & 4. I give the driver rating through the application after using an online motorcycle taxi & Y4 \\
\hline & 5. I use online motorcycle taxis based on my own initiative & Y5 \\
\hline
\end{tabular}

*) shows the indicator are not valid and reliable

\section{SEM Results}

Based on goodness of fit evaluation model described in Figure 2, this model showed that it has fulfilled the requirements and in good fit condition so this research model is feasible. The suitability test of the measurement model is done by validity test and reliability test. Based on the suitability test of the measurement model, the attributes contained in the model are declared valid because they have standardize loading factor (SLF) $\geq$ 0.5 . However, it does not include the Y3 indicator in processing for certification because the indicator has not met the requirements. Based on the compatibility test of the structural model, the hypothesis has been declared good and significant, except hypothesis 5 which is not significant.

Contribution of Dimensions and Indicators of Variables to Latent Variables

Each variable has dimensions and indicators that can be used to measure how the relationship between these variables, each indicator and dimension has a value that is used as a benchmark for assessing the role of the variable as large as possible. The variable dimension of marketing mix has the biggest contribution is the price and process with a value of loading factor of 1.00.
This indicates that the price and process factors are the most influential among other marketing mix factors applied in the process of offering services and facilities provided by online motorcycle taxis. The word of mouth variable indicator has the largest contribution rate is WOM2 with a value of 0.90 loading factor. The indicators providing recommendations (WOM2) contribute the most because the respondents more often give recommendations to the closest people about the experience of using motorcycle taxis online compared to other ways that respondents use to convey word of mouth.

The brand image indicator that has the greatest contribution is to feel safe when using an online motorcycle taxi (BI3) with a factor loading value of 0.69 . This indicates that the brand image embedded in respondent mindset regarding online motorcycle taxi is level of security because respondents can recognize the identity of the driver. The indicator of the behavior variable of service use has the biggest contribution is using an online motorcycle taxi on its own initiative (Y5) with a load factor value of 0.83 . Self-awareness in using motorcycle taxi is one of example initiative that chooses to use motorcycle taxi without any other party's coercive. 


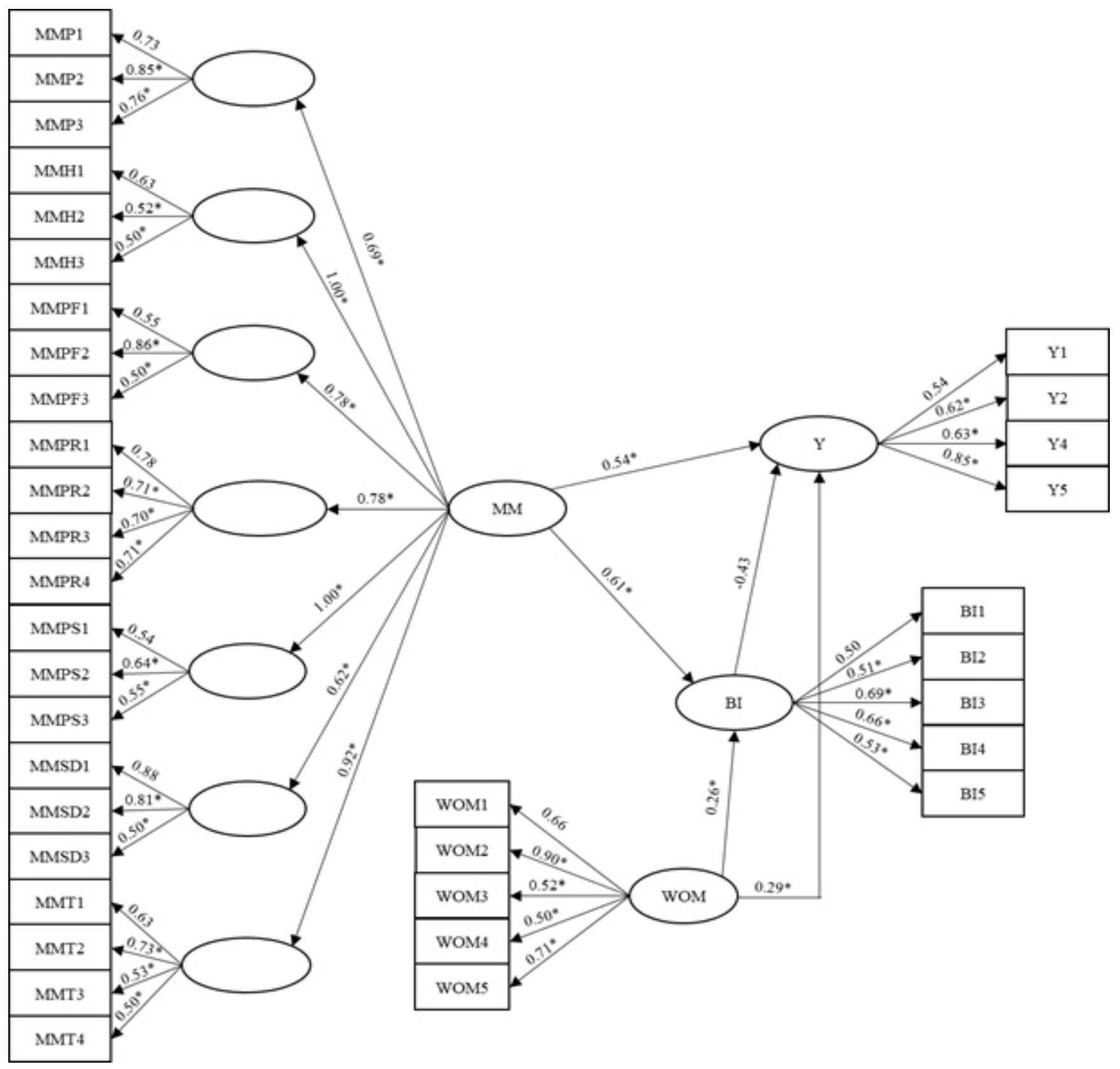

Figure 2. Measurement model of SEM ( $\left.{ }^{*}\right)$ shows t-value $>1.96$ so categorized as significant )

Influential factors towards usage behavior

Based on the model of SEM which is proposed to this research, the hypothesis testing has been conducted through the testing coefficients of structural equation model. Table 4 describes the results of the estimation model of SEM. If the value of the coefficient value $\geq$ 0.05 , t-count $>1.96$ so the influence of the specific variables included the significance category, but if the value of the coefficient value of $0.05<\mathrm{t}$-count $<1.96$ then the influence between the variables included in the category are not significant. The following further clarification regarding the results of the estimation model of SEM (Table 4).
As can be seen in the results of the hypothesis testing found in Table 4. The dominant factor is the marketing mix to brand image with a load factor of 0.61 and a marketing mix of consumer behavior with a load factor of 0.54 . The results of the hypothesis testing table show that the marketing mix variable has a significant effect on the brand image variable, it is supported by the results of previous studies. In the research of Hikmawati et al. (2015), relational marketing and marketing mix (marketing mix) have a significant effect on customer trust, but the marketing mix has a greater role on customer trust when compared to relational marketing. Falihah's research (2013) states that there is an influence on all mix variables marketing to the 
formation of brand image, but only price variables and physical evidence that significantly influence consumer purchasing decisions.

Word of mouth variables have a significant effect on brand image, this is supported by the results of Wicaksono and Seminari (2016) research which mention a significant influence between word of mouth on brand image. The results of the research conducted by Rahayu (2014), stated that there was a significant influence between WOM and the brand image of the company. WOM and the influential brand community amounted to 54.3 percent of the brand image and the rest was influenced by other factors not examined in the study. From the results of Jatmika's research (2014), it can be seen that there is a significant influence from WOM and Brand Image on consumer purchase intention.

The marketing mix variable has a significant effect on the behavior of use, this is supported by the results of research by Farida et al. (2016) where the marketing mix has a positive and significant effect on passenger satisfaction. In addition, from the results of Sukotjo and Radix (2010) research, it was stated that the variables in the $7 \mathrm{P}$ marketing mix concept (Product, price, promotion, place, participant, physical evidence, and process) had a positive influence on consumer purchasing decisions. Research by Rahayu et al (2015), states that there is a significant effect of the marketing mix in which there is a $7 \mathrm{P}$ element on consumer decisions in taking action to consume a service. Research by Marwa et al. (2014) produce that the marketing mix has a significant influence on consumer decisions, where there are five indicators that influence consumer purchasing decisions.
Word of mouth variable has a significant effect on usage behavior, this is supported by previous research conducted by Wuryanto (2007) and Nur (2014) with the results of the word of mouth variable having a positive and significant effect on consumer satisfaction and decision. A research conducted by Satwika (2011), results of the study showed that there was a significant effect between word of mouth on purchasing decisions. Furthermore, Fitriana (2011) conducted a study using three variables, namely WOM, brand image, and visit decision. The results of the study indicate that the WOM variable and brand image have a significant effect on the visit decision. Hendarwati (2015) research on WOM on purchasing decisions, shows a significant relationship between WOM and consumer purchasing decisions. The research of Widyaswati (2010) produces managerial implications for companies to improve service to consumers if they want to increase customer satisfaction and positive word of mouth can be created.

Brand image variables have no significant effect on usage behavior, this is supported by previous research conducted by Kaihatu (2012) where the brand image has no significant effect on customer service and satisfaction. In addition, according to Sakunlertvattana (2016), in his research aimed to identifying influential factors and brand choices by customers. The results of this study are that service or service has a very positive effect on brandtaxi mobile applications in Bangkok. Previous research on the brand image of Heriyati and Septi (2012), in the results of their research states that brand image has a significant influence on purchasing decisions. Meanwhile, there are studies that are in line with the results that brand image has no effect on usage behavior, such as a study from Desiarista and Triastuti (2011), stating that the brand image is not affected by the interest in buying.

Table 4. Estimation results of the SEM model

\begin{tabular}{lcccc}
\hline Variable influence & Path Coefficient & $\mid \mathrm{t}$-value $\mid$ & \multicolumn{2}{c}{ Conclusion } \\
\hline H1: Marketing mix $\rightarrow$ Brand Image & 0.61 & 17.30 & Significant & H1 Accepted \\
H2: Word of Mouth $($ WOM $) \rightarrow$ Brand Image & 0.26 & 6.32 & Significant & H2 Accepted \\
H3: Marketing mix $\rightarrow$ Consumer Behavior & 0.54 & 7.43 & Significant & H3 Accepted \\
H4: Word of Mouth $($ WOM $) \rightarrow$ Consumer Behavior & 0.29 & 5.11 & Significant & H4 Accepted \\
H5: Brand Image $\rightarrow$ Consumer Behavior & -0.43 & 1.92 & Not Significant & H5 Denied \\
\hline
\end{tabular}




\section{Managerial Implications}

There are some things that can be managerial implications of the company based on the results of this study, among them are in terms of the relevance of research variables on usage behavior. From the three independent variables, the variable that is not significant with the behavior of online motorcycle taxis is brand image. As an effort to increase brand image so it can affect the behavior of online motorcycle taxis is doing a research towards consumer needs to see their characters and their needs to be more profound, for example approaching consumers using the STP (Segmentation, Targeting, and Positioning) method. Building relationships with consumers that continue to be continuous (long term relationship) so that the brands they have can be directly embedded in the minds of consumers.

\section{CONCLUSIONS AND RECOMMENDATIONS}

\section{Conclusions}

Based on the results of research on online motorcycle taxis behavior from the three existing brands, it can be seen that the respondents' ranks of online motorcycle taxi users are Grab brand users (96.0\%), Go-jek $(89.5 \%)$, and Uber $(56.5 \%)$. The frequency of use with the rarely used category is dominated by Uber (66.4\%), the frequently used category is dominated by Grab (46.9\%) and always used is dominated by Grab (12.5\%). The majority of Uber user respondents always pay in cash, while 3 out of 10 respondents Go-jek pay non-cash using Go-pay. Most Grab user respondents gave ratings as feedback, more than 10 percent of Uber users gave comments as feedback and 16.2 percent of examples of Go-jek users gave ratings and comments as feedback.

Marketing mix and word of mouth variable both have a significant effect on brand image. They both have a big role in creating an image that can be stored in the mindset of consumers, so that consumers can easily describe a brand through marketing mix and word of mouth. Marketing mix and word of mouth variabl also significantly influence the behavior of online motorcycle taxi usage behavior. Both of these variables can influence the decisions and behavior of a consumer in using an online motorcycle taxi, for example in the marketing mix show consumers are considering price as a main reason while in word of mouth there are recommendations from the closest people about the experience of using motorcycle taxi products or services online. Brand image variables do not significantly influence the usage behavior, so it can be assumed that the brand image of an online motorcycle taxi does not affect the usage behavior and decision of a consumer if indeed in public transportation conditions immediately.

\section{Recommendations}

The marketing mix variable in this study uses seven approach factors or 7P (seven $\mathrm{P}$ ) contained in the service marketing mix, so there is a possibility for the next research to add some additional determinants in the marketing mix that has been developed at this time so that the research results are more profound, including proof, picture, and personality. In addition, the online motorcycle taxi brands studied in this study consisted of Grab, Go-jek and Uber. However, if there are other online motorcycle taxi brands that are often used by consumers in the future as well as the three online motorcycle taxi brands, there is a possibility that further research can examine online motorcycle taxi brands both in depth in one company and the overall brand.

\section{REFERENCES}

Aprilia TL. Pengaruh brand image produk apple terhadap keputusan pembelian konsumen pada komunitas instamarinda. eJournal Ilmu Komunikasi Universitas Mulawarman 4(3): 421-431.

Desiarista E, Triastuti SR. 2011. Analisis pengaruh iklan, kepercayaan merek, dan citra merek terhadap minat beli konsumen. Jurnal Universitas Diponegoro Aset 13(1): 37-45.

Falihah N. 2013. Pengaruh strategi bauran pemasaran kepada pembentukan brand image dan dampaknya kepada keputusan pembelian [tesis]. Jakarta: Universitas Terbuka.

Farida I, Tarmizi A, November Y. 2016. Analisis pengaruh bauran pemasaran $7 \mathrm{P}$ terhadap kepuasan pelanggan pengguna ojek online. Jurnal Riset Manajemen dan Bisnis 1(1): 31-40. https://doi.org/10.36226/jrmb.v1i1.8.

Fitriana N. 2011. Analisis pengaruh promosi word of mouth terhadap brand image dan proses 
keputusan kunjungan kebun raya bogor [skripsi]. Bogor: Institut Pertanian Bogor.

Hendarwati A. 2015. Analisis pengaruh dimensi word of mouth communication terhadap keputusan pembelian sajian kuliner lapak angkringan. Jurnal STIEBBANK 593-609.

Heriyati P, Septi. 2012. Analisis pengaruh brand image dan kualitas produk terhadap keputusan pembelian konsumen pada handphone nexian. Journal of Business Strategy and Execution 4(2): 171-205.

HikmawatiNK, Damey D. 2014. Relationship marketing and marketing mix of customer value and brand image and its impact on customer trust. Journal Business Management Padjadjaran University.

Hikmawati NK, Sucherly, Sumawihardja S. 2015. Influence of marketing relations and marketing mix on customer trust on mobile service operators in Indonesia. International Journal Of Economics, Commerce and Management 3 : 409-422.

Jatmika CS. 2014. Pengaruh elektronik word of mouth terhadap brand image dan purchase intention smartphone samsung di Surabaya. Calyptra. Jurnal Ilmiah Mahasiswa Universitas Surabaya $3(2)$.

Kaihatu TS. 2012. Kepuasan konsumen yang dipengaruhi oleh kualitas layanan dengan brand image sebagai variabel perantara: Studi Kasus pada Konsumen Rumah Sakit Swasta di Kota Surabaya. Jurnal Mitra Ekonomi dan Manajemen Bisnis 3(2) : 200-210.

Keller, Kevin Lane. 1998. Strategic Brand Management, Building, Measuring, and Managing Brand Equity. New Jersey: Prentice Hall.

Kotler P. 2004. Manajemen Pemasaran. Edisi Milenium. Jakarta: PT Indeks Kelompok Gramedia.

Kotler P.2000. Manajemen Pemasaran. Jakarta: PT. Prenhalindo.

Lupiyoadi H. 2006. Manajemen Pemasaran dan Pemasaran Jasa. Cetakan Ke-7. Bandung : Alfabeta.

Marwa S, Sumarwan U, Nurmalina R. 2014. Bauran pemasaran mempengaruhi keputusan konsumen dalam pembelian asuransi jiwa individu. Jurnal Ilmu Keluarga dan Konsumen 7: 183-192. https://doi.org/10.24156/jikk.2014.7.3.183.

Merthayoga WPI, Sunaryo S. 2013. Analisis pengaruh kualitas pelayanan, citra merek, dan word of mouth terhadap minat beli konsumen dengan metode structural equastion modeling (studi kasus : peminat produk ponsel X di Surabaya). Seminar Nasional Manajemen Teknologi XVII. Surabaya: Jurnal Institut Teknologi Sepuluh November Surabaya.

Monroe, Allard CR van Riel. 2005. Marketing antecedent of industrial brand equity: an empirical investigation in specialty chemical. Journal Industrial Marketing Management (12): 841-847. https://doi.org/10.1016/j. indmarman.2005.01.006.

Nur KM. 2014. Analisis pengaruh word of mouth dan marketing mix terhadap keputusan pembelian prol tape primadona melalui brand image [tesis]. Bogor: Institut Pertanian Bogor.

Rahayu DD. 2014. Pengaruh word of mouth dan brand community komunitas sepak bola di Pekanbaru terhadap brand image. Jurnal Ekonomi 22 (1).

Rahayu I, Nurrochmat DR, Fachrodji A. 2015. Marketing mix analysis of natural tourism area 'Kawah Putih' and its effect on visitors decision. Indonesian Journal of Business and Entrepreneurship 1(2): 72-80.

Rahman S. 2011. Evaluation of definitions: ten dimensions of corporate social responsibility. Journal World Review of Business Research 1(1): $166-176$.

Satwika DR. 2011. Analisis pengaruh promitonal dan pengaruh word of mouth terhadap pengambilan keputusan konsumen dalam membeli produk asuransi jiwa [skripsi]. Jakarta: UIN Syarif Hidayatullah.

Sernovitz A. 2006. Word of Mouth Marketing: How Smart Companies Get People Talking. Chicago: Kaplan Publishing.

Sukotjo H, A Radix S. 2010. Analisa marketing mix7P (product, price, promotion, place, partisipant, process, dan physical evidence) terhadap keputusan pembelian produk klinik kecantikan teta di Surabaya. Jurnal Mitra Ekonomi dan Manajemen Bisnis (1)2: 216-228.

Wardhana A, Konadi W. 2015. Analysis of factors consumer preferences ojek online in indonesia using conjoint technique analysis; 2015 November 7-8; Bireuen, Indonesia: Almuslim International Conference on Science, Technology and Society (AICTS).

Wicaksono MPA, Seminari NK. 2016. Pengaruh iklan dan word of mouth terhadap brand awareness traveloka. E-Jurnal Manajemen Unud 5(8): 5098-5127.

Widyaswati R. 2010. Analisis faktor-faktor yang 
mempengaruhi kepuasan sehingga tercipta word of mouth yang positif pada pelanggan speedy di Semarang [tesis]. Semarang: Universitas Diponegoro.
Wuryanto BA. 2007. Analisis faktor-faktor yang mempengaruhi kinerja Word of Mouth marketing (WOM) [tesis]. Semarang: Universitas Diponegoro. 